\title{
THE IMPACT ON REGIONAL DEVELOPMENT OF POLES OF SOCIO-ECONOMIC GROWTH WHICH GENERATED BASED ON TRANSPORT NODES AND NETWORKS
}

\author{
Nataliia PASHYNSKA \\ Institute of Geography, National Academy of Sciences, Kyiv, Ukraine \\ n_pashynska@ukr.net
}

\begin{abstract}
The article analyzes the current trends in development of transport and directions its impact on regional development. Approaches to the study of transportation from position forming poles of socio-economic growth discovered. There is a brief description of transport nodes and networks as poles of socio-economic growth and determining their impact on growth of economic and social activity in the regions.
\end{abstract}

Key words: transportation, regional development, pole of socio-economic growth, transport node, transport corridor, transport network.

UDC: 911.3

\section{ВПЛИВ НА РЕГІОНАЛЬНИЙ РОЗВИТОК ПОЛЮСІВ СОЦІАЛЬНО-ЕКОНОМІЧНОГО ЗРОСТАННЯ, ЩО ФОРМУЮТЬСЯ НА ОСНОВІ ТРАНСПОРТНИХ ВУЗЛІВ ТА МЕРЕЖ}

\author{
Наталія ПАШИНСЬКА \\ Інститут географії НАН України, м. Київ, Україна \\ n_pashynska@ukr.net
}

\begin{abstract}
Анотація: У статті проаналізовано сучасні тенденції розвитку транспорту та розглянуто напрями його впливу на регіональний розвиток. Виявлено підходи до дослідження транспорту з позицій формування полюсів соціально-економічного зростання. Дано коротку характеристику транспортних вузлів та мереж як полюсів соціально-економічного зростання та виявлено їх вплив на посилення економічної та соціальної активності в регіонах.
\end{abstract}

Ключові слова: транспорт, регіональний розвиток, полюс соціально-економічного зростання, транспортний вузол, транспортний коридор, транспортна мережа.

УДК: 911.3

Вступ. Постановка проблеми. Практика регіонального розвитку країн Європейського Союзу показала, що значний синергетичний ефект на активізацію соціально-економічного розвитку спричиняють проекти «полюсів зростання», що охоплюють інфраструктурні сфери, які покращують регіональну та локальну доступність, зумовлюють рівномірний та інтегрований регіональний розвиток. Насамперед йдеться про заходи удосконалення соціальної інфраструктури, модернізацію міського транспорту, дорожнє та транспортне будівництво, покращення інфраструктури мереж комунікаційних та інформаційних технологій, що забезпечують кращі зв'язки між міськими зонами та віддаленими від них районами [6].

У сучасних теоріях кумулятивного росту під полюсами зростання розуміють центри й ареали економічного простору, що концентрують прогресивні (пропульсивні) види економічної діяльності (виробництво та сфера послуг), які активно розвиваються й розширюються, і здатні викликати подальший розвиток економічної діяльності у всій зоні свого впливу. Одним із пропульсивних видів економічної діяльності $\epsilon$ транспортна діяльність, розвиток якої зумовлює підвищення транспортної доступності, мобільності та зв'язності території, іiі конкурентоспроможності.

(C) Н. Пашинська
Аналіз останніх досліджень і публікацій. Аналіз тематики провідного світового видання 3 географії транспорту «Journal of Transport Geography» показав, що в останнє десятиліття зросла увага до дослідження впливу великомасштабних транспортних проектів на підвищення соціально-економічного розвитку регіонів, серед яких міжнародні транспортні коридори, впровадження швидкісного залізничного руху, спорудження потужних транспортних терміналів, аеропортів, портів [3].

Про це свідчить i тематика роботи окремих секцій Міжнародного географічного конгресу у Кельні (2012), що були присвячені великомасштабним проектам транспортної інфраструктури та ix впливу на регіональний i міський розвиток (20 доповідей), зонам впливу портів та міській логістиці (4 доповіді), змінам в логістичних мережах: трансформація відстані та просторові наслідки (4 доповіді) [4].

Разом 3 тим, в українській географії практично відсутні дослідження 3 комплексної оцінки впливу транспортного чинника на регіональний розвиток. Донедавна, оцінка транспортної складової територіальних комплексів різного ієрархічного рівня обмежувалася використанням концепції транспортногеографічного положення або транспорт розглядався як специфічний елемент народного господарства i сфери обслуговування (пасажирський транспорт) у 
межах різних економічних та економіко-географічних концепцій. Проте, у зв'язку 3 концентрацією транспортних потоків, інтеграцією транспортних систем, посиленням функціонального підходу виникли нові форми територіальної організації, що потребують вивчення та розуміння їх значення у сучасному регіональному розвитку.

Метою статті є дослідження напрямів впливу транспорту, зокрема транспортних вузлів та мереж, на регіональний розвиток у контексті формування полюсів соціально-економічного зростання.

Виклад основного матеріалу. У сучасних дослідженнях транспорт розглядається як комунікаційна інфраструктурна галузь, що поєднує всі елементи територіальної структури господарства i розселення в єдину систему шляхом переміщення (перевезення) транспортними мережами людей, вантажів, інформації і енергії. До основних функцій транспорту відносяться просторова інтеграція, територіальне сполучення (комунікаційна функція), транзит, подолання простору, транспортне обслуговування території і населення. Рівень розвитку транспортної інфраструктури значно впливає на витрати 3 перевезень вантажів і пасажирів, мобільність; визначає транспортну доступність населених пунктів, формує просторову зв'язність території, зумовлюючи ступінь соціально-економічного розвитку регіону в цілому. Стан транспортних комунікацій - одна 3 найбільш принципових умов інвестиційного процесу, розвитку туристичного бізнесу. Країни, які у свій час визначили розвиток транспортних комунікацій серед основних пріоритетів економічної політики, у результаті отримали не лише розвинений сегмент транспортної інфраструктури, але й стимулювали економічне зростання та досягли позивних результатів у вирішенні проблем зайнятості. Разом 3 тим, нині експорт транспортних послуг є суттєвою складовою експортного потенціалу України (понад 70\% загального експорту послуг).

Зазначимо, що нині кардинально змінилися підходи до ролі транспорту. Вийшли на перший план якісні характеристики функціонування транспортної системи, серед яких підвищення якісних показників роботи транспорту, серед яких комфортність, швидкість, точність, гнучкість, адресність, надійність, збереженість вантажу, безпечність (впровадження принципу доставки “just-in-time”). Відповідно до цього відбулися зміни парадигми у регіональному плануванні та плануванні транспорту - відхід від планування об'ємних показників до планування соціально-орієнтованих індикаторів, що відображає поворот від виробників транспортних послуг до ї споживачів.

Важлива роль транспортної інфраструктури для регіонального розвитку є одним 3 основоположних принципів регіональної економіки. У простій формі iii значення полягає у тому, що райони з кращою доступністю до місць сировини та ринків, за інших рівних умов, більш продуктивніші та конкурентоздатні та відповідно більш успішніші, ніж ті, що розташовані віддалено та ізольовано [7]. Ефективні транспортні системи забезпечують економічні та соціальні можливості і переваги в результаті позитивних ефектів мультиплікатора, зокрема зниження транспортних витрат, підвищення доступності до ринків, зайнятості та додаткових інвестицій.

Останнім часом посилилася увага до емпіричних досліджень впливу транспортної інфраструктури на регіональний розвиток. Виявлено чітку позитивну кореляцію між рівнем розвитку транспортної інфраструктури i рівнем економічних показників, зокрема таких як обсяги ВВП на особу населення. Разом 3 тим, у країнах 3 високорозвинутою транспортною інфраструктурою подальше вдосконалення транспортної мережі часто зумовлює не такі суттєві економічні переваги, ніж у державах, що мають низький рівень розвитку транспорту. Це зумовлено тим, що поліпшення транспортної інфраструктури має значний вплив на регіональний розвиток тільки тоді, коли воно призводить до усунення «вузьких місць» у іiі розвитку (підвищення пропускної спроможності, транспортної доступності). Також слід враховувати, що транспорт виконує значну соціальну функцію та здійснює вагомий вплив на довкілля [1].

Загалом можна виділити 4 ключові підходи до дослідження впливу транспорту на соціальноекономічний розвиток регіону:

- ступінь впливу транспорту на доступність до ринків сировини та збуту;

- скорочення транспортних витрат;

- аналіз інвестиційної активності у транспортній галузі;

- підвищення якісних характеристик та мобільності [9].

Таким чином, вплив транспорту на регіональний розвиток можна зобразити у вигляді циклічної схеми, що підкреслює тісну взаємодію та взаємопов'язаність транспорту і більшості соціально-економічних процесів у регіоні. Вона демонструє, що рівень розвитку транспорту визначає доступність, привабливість, конкурентоспроможність регіону, впливаючи на розміщення підприємств та населення, економічну активність у регіоні та мобільність населення та ресурсів. I в той же час, залежно від розміщення видів діяльності, економічної активності у регіоні виникають потреби у транспорті, розвитку відповідних видів транспорту, його розміщення, що зумовлює концентрацію транспортних мереж та потоків (рис. 1). Спорудження полімагістралей i транспортних коридорів, мультимодальних транспортних вузлів, що об'єднують різні види транспорту для обслуговування потужних вантажо- i пасажиропотоків, стають імпульсом для формування полюсів соціально-економічного зростання 3 метою подальшого стимулювання розвитку регіонів.

Таким чином, 3 позицій формування полюсів зростання транспортну діяльність слід розглядати у двох аспектах:

- Транспорт як вид діяльності, що виступає мультиплікатором для розвитку полюсів зростання. Об'єктами для дослідження у цьому контексті 
$€$ транспортні вузли та полімагістралі, у яких відбувається концентрація транспортної діяльності (інфраструктури та потоків).

- Транспорт як вид діяльності, що зв’язує та об'єднує в мережу полюси зростання, забезпечуючи зв'язки між ними та потоки товарів, послуг, людей.

Для сучасного транспорту характерна концентрація транспортної діяльності, інфраструктури та потоків у точкових (вузли) і лінійних територіальних елементах (полімагістралі).

Транспортний вузол - територіально-виробнича система, що функціонально об'єднує роботу різних видів транспорту і забезпечує, у взаємодії з транспортною клієнтурою, концентрацію, обробку, розосередження вантажо- та пасажиропотоків у трьох та більше магістральних напрямах. Територіально найбільш чітко відокремлюються залізничні вузли, що мають виразні межі. Досить часто межі транспортних вузлів можуть співпадати 3 межами міських агломерацій. Класифікація транспортних вузлів здійснюється за співвідношенням видів транспорту, за значенням, функціями, транспортним балансом, величиною вантажо- та пасажирообігу, інтенсивністю роботи.

Територіальну структуру транспортного вузла складають ядро, зона безпосереднього обслуговування та район тяжіння. Логістичний підхід до функціонування транспортних вузлів передбачає необхідність диверсифікації діяльності транспортних вузлів, розширення спектру послуг, що надаються клієнтові, що не пов'язані безпосередньо 3 перевезеннями (зберігання, обробка вантажів) [5].

Під час дослідження транспортних вузлів важливо виявити ці вузли, визначити вплив соціально-економічних та інших чинників (природногеографічних, історичних, культурних, політичних, геополітичних) на їх розвиток, визначити економікогеографічне положення, функції та роль у транспортній системі, зв'язки $з$ місцевим господарством, зони впливу та тяжіння. Провести типізацію вузлів та визначити їх місце в ієрархії транспортної системи, встановити обернений зв'язок і вплив функціонування транспортного вузла на соціально-економічний розвиток регіону.

Розширення соціально-економічних зв'язків, зростання торговельних потоків між країнами та регіонами, їх концентрація, впровадження нових прогресивних логістичних транспортних технологій обумовили формування нових вузлових елементів транспортної мережі, серед яких термінали, хаби, гетвеї, транспортно-логістичні центри [2].

Території, що розміщені між полюсами зростання, завдяки розвитку транспортної мережі отримують додаткові імпульси росту в результаті збільшення вантажопотоків, розповсюдження інновацій, розвитку інфраструктури. Тому вони перетворюються у вісі

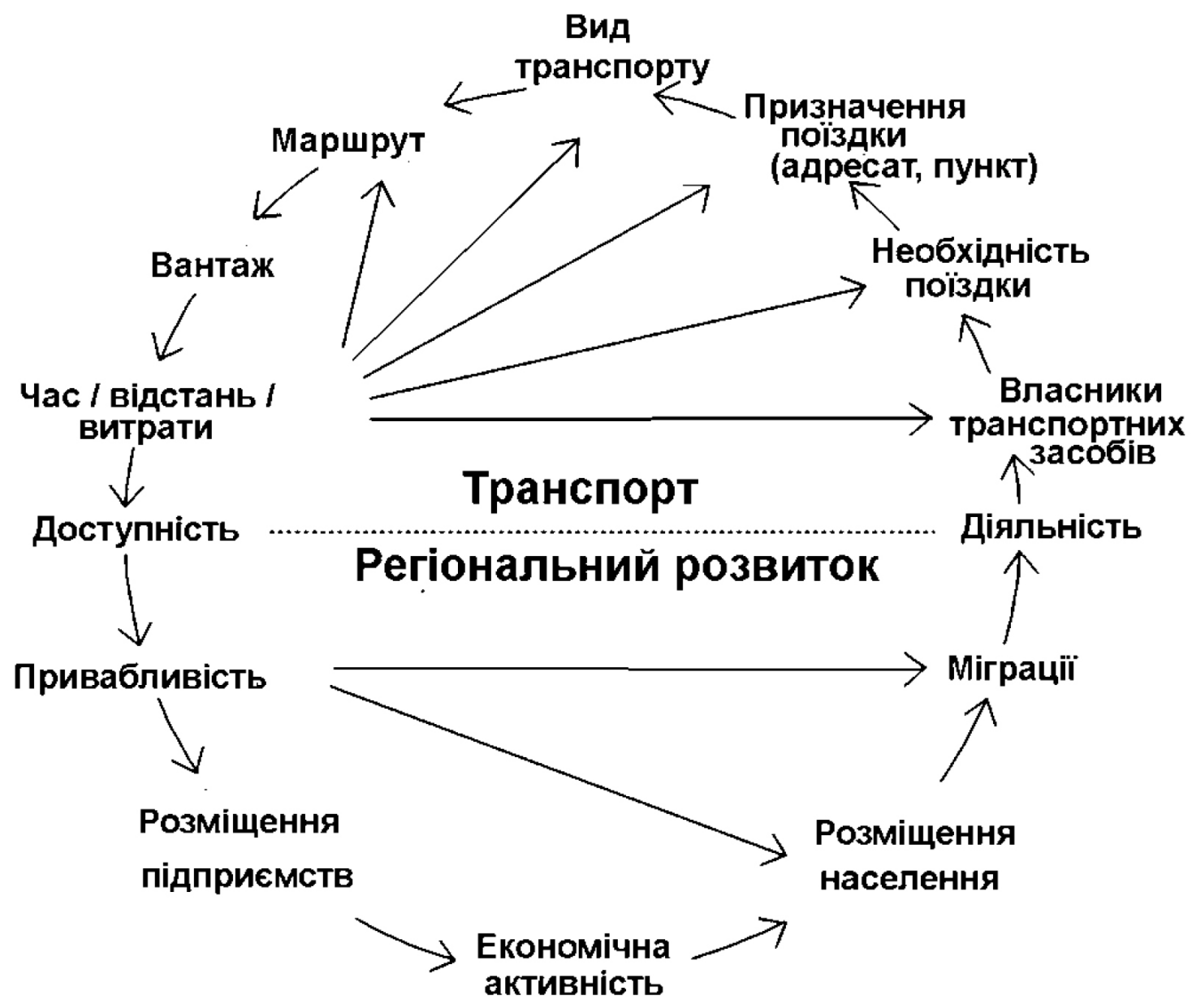

Рис. 1. Схема впливу транспорту на регіональний розвиток 
(коридори) розвитку, що визначають разом із полюсами зростання просторовий каркас економічного зростання великого регіону чи країни. Відповідно до цього, у світовій економіці існує аксіома: чим більшою є щільність шляхів сполучення на території держави, тим вищим є рівень їі економічного розвитку.

Найбільш потужні транспортні потоки вантажів, населення i інформації підтримують та концентрують полімагістралі та транспортні коридори. Полімагістралі - це система паралельних ліній декількох видів транспорту і лінійної інфраструктури (залізничні, автомобільні дороги, трубопроводи), що зосереджена вздовж однієї смуги території. Протяжні полімагістралі, що зв'язують декілька районів або країн, формують транспортні коридори [10].

Важливою формою реалізації транзитного потенціалу території $€$ міжнародні транспортні коридори (МТК), що формуються під впливом зростання обсягів міжнародної торгівлі та збільшення транснаціональних транспортних потоків. $\boldsymbol{M T K}$ - це комплекс наземних та водних транспортних магістралей 3 відповідною інфраструктурою, допоміжними спорудами, під’їзними шляхами, прикордонними переходами, сервісними пунктами, вантажними та пасажирськими терміналами, устаткуванням для управління рухом [8].

Таким чином, транспортні мережі виступають опорним каркасом, що поєднує центри, вузли та полюси соціально-економічного зростання. Концентрація мереж та проходження доріг міжнародного значенню формують вісі розвитку або коридори розвитку (транспортні коридори).

Висновки. Стимулювання розвитку полюсів соціально-економічного зростання нині $€$ важливою складовою успіху регіональної політики багатьох держав світу. Одним із пропульсивних видів економічної діяльності є транспортна діяльність, розвиток якої зумовлює підвищення транспортної доступності, мобільності та зв'язності території, iіi конкурентоспроможності. У цьому напрямі важливе значення мають процеси концентрації транспортних потоків, формування полімагістралей і транспортних коридорів, мультимодальних транспортних вузлів, що об'єднують різні види транспорту для обслуговування потужних вантажо- i пасажиропотоків. Розвиток транспортних вузлів, транспортнологістичних комплексів та терміналів стає імпульсом для розвитку торгівлі, туризму, зайнятості населення, зростання доходів та підвищення рівня соціальноекономічного розвитку регіону в цілому.

\section{References:}

1. Banistera D., Berechmanb Y. Transport investment and the promotion of economic growth. Journal of Transport Geography, 2001. Vol. 9, pp. 209-218. Vol. 237-240.

3. Hall D. Impacts of economic and political transition on the transport geography of Central and Eastern Europe. Journal of Transport Geography, 2003, Vol. 1, pp. 20-35

4. 32nd International Geographical Congress. Book of Abstracts. Cologne, 2012, 979 p.

5. Kaûčkin N.P. Geografičeskie osnovy transportnogo osvoeniâ territorii [Geographical bases of the transport development of the territory]. Moscow, 2003, 163 p. (In Russian).

6. Key achievements of Regional Policy/Regional Policy [European Commission] - Access mode: http://ec.europa. eu/regional policy/en/policy/what/key-achievements/.

7. Linneker B. Transport Infrastructure and Regional Economic Development in Europe: A Review of Theoretical and Methodological Approaches. University of Sheffield, 1997, 165 p.

8. Novikova A.M. Ukraïna v sistemi mižnarodnih transportnih koridorìv [Ukraine in system of international transport corridors]. Kyiv, 2003, 494 p. (In Ukrainian).

9. Ŝerbanin U.A. Transport i èkonomičeskij rost: vzaimosvâz' $i$ vliânie [Transport and economic growth: the relationship and the impact]. Evrazijskaâ èkonomičeskaâ integraciâ [Eurasian Economic Integration]. 2011, Vol. 3 (12), pp. 65-78 (In Russian).

10. Tarhov S.A. Èvolûcionnaâ morfologiâ transportnyh setej [Evolutional morphology of transport networks]. Smolensk-Moscow, 2005, 384 p. (In Russian). 